\title{
Glycobiology of Sialyl 6-Sulfo Lewis x, a New Carbohydrate Ligand for Selectins
}

\author{
新規セレクチンリガンド、シアリル 6 -スルホルイスxのグリコバイオロジー
}

\author{
Kannagi, Reiji; and Kanamori, Akiko \\ Aichi Cancer Center, Department of Molecular Pathology, Kanokoden, \\ Chikusa-ku, Nagoya 464-8681, Japan \\ FAX:81-52-763-5233, E-mail: rkannagi@aichi-cc.pref.aichi.jp
}

\begin{abstract}
Key words:fucosyltransferase, sialyltransferase, 6-O-sulfotransferase, high endothelial venule (HEV), helper memory T lymphocyte
\end{abstract}

\begin{abstract}
Selectin is a family of cell adhesion molecules expressed on endothelial cells, leukocytes and platelets. It is implicated in extravasation of leukocytes, homing of lymphocytes, and infiltration or metastasis of malignant cells including leukemia cells and cancer cells. Sialyl Lewis x, sialyl Lewis a and several other carbohydrate determinants have been known to serve as carbohydrate ligands for selectins. The most-recently described selectin ligand is sialyl 6-sulfo Lewis $\mathrm{x}$. This determinant was first described as a major lymphocyte homing receptor for Lselectin expressed on high endothelial venules of human lymph nodes, and later found to be expressed on certain subsets of lymphocytes and on some cells of epithelial origin, also serving as a ligand for E- and/or P-selectin. Expression of sialyl 6-sulfo Lewis $\mathrm{x}$ is regulated differently from that of conventional sialyl Lewis $\mathrm{x}$ in that it is metabolized through a distinct metabolic pathway involving the cyclization of sialic acid moiety. In this article we will review the distribution, synthesis and metabolic fate of this new selectin ligand, and discuss its physiological significance.
\end{abstract}

要 約

セレクチンは血管内皮細胞、白血球、血小板などに発現す る細胞接着分子のファミリーであり、白血球の血管外脱出、リ ンパ球のホーミング、悪性細胞の浸潤や転移に関与するとされ

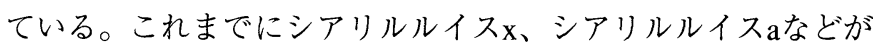
セレクチンの糖鎖リガンドであることが判明している。最も新 しくセレクチンのリガンドであることが判明した糖鎖はシアリ ル6-スルホルイスxである。シアリル6-スルホルイスxは、はじ めはヒト末梢リンパ節の高血管内皮細静脈の内皮細胞に発現す るホーミングリセプターで、L-セレクチンと結合するリガンド として見出された.その後、一部のリンパ球サブセットや上皮細 胞にも発現し、E-セレクチンやP-セレクチンのリガンドとして もはたらくことが判明している。シアリル6-スルホルイスxの 発現の調節機構は、通常のシアリルルイスxと大きく異なり、シ アル酸部分の環状化を介したユニークな経路で代謝される。本 稿では、この新規のセレクチンリガンドについて、その発現の 分布や合成・異化の機構を紹介し、その生理的意義を考察して みたい。

\section{A. Selectins and Their Carbohydrate Ligands}

The selectin family consists of three glycoprotein members: E-, P- and L-selectin. Each selectin has a calcium-dependent carbohydrate binding domain (C-type lectin domain) in its amino terminus, followed by an epidermal growth factor (EGF)like domain, a varying number of complement-binding proteinlike repeats, a transmembrane domain and a short cytoplasmic domain. Sialyl Lewis $\mathrm{x}$ determinant was first reported to be a carbohydrate ligand for E-selectin (1-3), and later its anomeric determinant sialyl Lewis a was found to serve as another carbohydrate ligand for E-selectin (4-6). Because the C-type lectin domains of the three members of the selectin family had been known to be considerably homologous, it had been predicted that sialyl Lewis $\mathrm{x}$ and/or sialyl Lewis a could also serve as ligand for $\mathrm{P}$ - and L-selectins, and the significant in vitro binding of $\mathrm{P}$ and L-selectins to sialyl Lewis $\mathrm{x} / \mathrm{a}$ determinants was reported by several groups of researchers.
A. セレクチンとその糖鎖リガンド

セレクチンファミリーの細胞接着分子には、E-、P-および L-セレクチンの三者があり、いずれもアミノ末端から順に、糖 鎖結合ドメイン（C-タイプレクチンドメイン）、EGF様ドメイ ン、数個の補体結合タンパク様ドメイン、膜貫通ドメインおよ び短い細胞質ドメインを持つ。まずはじめにE-セレクチンの糖 鎖リガンドがシアリルルイスxであることが判明し(1-3)、続いて シアリルルイス $\mathrm{a}$ またE-セレクチンのリガンドであることが見 出された(4-6)。C-タイプレクチンドメインはセレクチンファミ リーの三者間で相同性が高いため、シアリルルイスxやシアリル ルイスaは、E-セレクチンのみならず P-および L-セレクチンの 糖鎖リガンドである可能性があると考えられていたので、やが てこれらの糖鎖がP-およびL-セレクチンのリガンドでもあると する報告がいくつかあらわれた。 
However, there are differences in binding specificity among these three species of selectins. Recently it has become increasingly clear that each selectin member has its own distinct ligand specificity. For instance, L-selectin is supposed to bind to the carbohydrate ligand expressed on the endothelial cells lining the high endothelial venules (HEV) of peripheral lymph nodes. However, most of the anti-sialyl Lewis $\mathrm{x}$ or antisialyl Lewis a antibodies, which readily detect E-selectin ligand on other cells and tissues, fail to react to HEV endothelial cells (7). This suggests that the ligand on HEV endothelial cells recognized by L-selectin is different from conventional sialyl Lewis $\mathrm{x}$ or sialyl Lewis a defined by those antibodies. These findings led to the identification of the sialyl 6-sulfated Lewis $\mathrm{x}$ determinant as a ligand for L-selectin on human HEV (8-10). In this article we will review recent progress in the study of the ligand activity of this newly found carbohydrate ligand for each member of the selectin family cell adhesion molecules.

\section{B. Characteristics of L-Selectin-Mediated Cell adhesion}

L-selectin (LAM-1, LECAM-1, gp90 ${ }^{\text {mel }}$, or CD62L) is constitutively expressed on leukocytes. L-selectin was first described as a lymph node receptor involved in the homing of lymphocytes to peripheral lymph nodes $(11,12)$. High endothelial venules (HEV) are known to serve as an entrance for those lymphocytes homing into peripheral lymph nodes. Thus, endothelial cells of HEV should constantly express carbohydrate ligands for L-selectin, such as sialyl Lewis $\mathrm{x}$ or sialyl Lewis a. Subsequently, L-selectin was also implicated in the leukocyte-leukocyte interaction and/or neutrophil-endothelial interaction at the site of inflammation $(13,14)$. If L-selectin is involved in the adhesion of leukocytes to vascular endothelial cells at the site of an inflammatory lesion, the putative L-selectin ligand on endothelial cells should be inducibly expressed by the inflammatory stimuli.

In immunohistochemical studies using anti-sialyl Lewis $x$ antibodies, the HEV endothelial cells in human lymph nodes showed a peculiar staining pattern. These cells were stained by only a limited group of anti-sialyl Lewis $\mathrm{x}$ antibodies, but not by other anti-sialyl Lewis $\mathrm{x}$ antibodies (Table I). The group of antibodies that stained HEV endothelial cells included $2 \mathrm{H} 5,2 \mathrm{~F} 3$ and HECA-452 $(7,8)$. Some of these antibodies inhibited the Lselectin-dependent cell adhesion to HEV (7). The group of antibodies which did not stain HEV endothelial cells included CSLEX-1, SNH-3 and FH-6, the three well-known classical antisialyl Lewis $\mathrm{x}$ antibodies. These findings indicated that a unique sialyl Lewis $\mathrm{x}$-like determinant, but not the authentic sialyl Lewis $\mathrm{x}$, was present on HEV endothelial cells, and served as a ligand for L-selectin. This was further supported by the finding that most of the anti-Lewis $\mathrm{x}$ antibodies failed to stain the sialidasetreated HEV endothelial cells. The genuine sialyl Lewis $\mathrm{x}$, after sialidase treatment, should have yielded conventional Lewis $\mathrm{x}$,
しかし、セレクチンファミリーの三者間には糖鎖との結合 の特異性に多くの点で相違があり、それぞれが独特の結合特異 性をもつことがだんだん判明してきた。例えばL-セレクチンの 糖鎖リガンドは、末梢リンパ節の高血管内皮細静脈（HEV）の 内皮細胞に発現しているはずである。しかし、ほとんどの抗シ アリルルイス $\mathrm{x}$ 抗体や抗シアリルルイス $\mathrm{a}$ 抗体は、他の細胞や組 織のE-セレクチンのリガンドを容易に検出するにもかかわら ず、HEVとは反応しない(7)。このことは、HEV上のL-セレクチ ンリガンドが、通常のシアリルルイス xやシアリルルイスaとは 異なることを示している。このことが、のちにシアリル6-スル ホルイスxがHEV上の L-セレクチンリガンドであると同定され るきっかけとなった(8-10)。この新規のセレクチンリガンドであ るシアリル 6-スルホルイスxは、L-セレクチンをはじめ三つの セレクチンに対してリガンド活性を有する。本稿では、この点 についての研究の最近の展開を紹介したい。

\section{B. L-セレクチンを介した細胞接着の特徵}

L-セレクチン(LAM-1、LECAM-1、gp90 mel CD62Lともいう) は、白血球に構成的に発現しており、はじめ、リンパ球のリン パ節へのホーミングを媒介する接着分子として記載された(11、 12)。リンパ球は、末梢リンパ節の高血管内皮細静脈を通ってリ ンパ節ヘホーミングする。もしL-セレクチンがリンパ球のリン パ節へのホーミングを媒介するならば、ホーミングの入り口に あたるリンパ節の高血管内皮静脈(HEV)の血管内皮細胞には、Lセレクチンに対応する糖鎖リガンドが発現されているのでなけ ればならない。また、L-セレクチンが、炎症時の白血球の血管 内皮細胞への接着に関与する(13、14)とすれば、さらにHEV以外 の一般組織の血管内皮細胞にも、少なくとも炎症時には、L-セ レクチンの糖鎖リガンドが発現されていることになる。

抗シアリルルイスx抗体でヒトの末梢リンパ節を染色する と、HEVは、一部の抗シアリルルイスx抗体でのみ染色され、他 の抗シアリルルイス抗体では染色されない。抗シアリルルイス x抗体のうち、2H5、2F3 PHECA-452はヒトHEVとの反応性を有 する(7、8)。これらの抗体の一部は、HEVへのL-セレクチン依存 性の接着を阻止する(7)。これに対して、古典的な抗シアリルル イスx抗体であるCSLEX-1、FH-6、SNH-3はいずれもHEVとほと んど反応しない。こうして抗シアリルルイスx抗体は、HEVと反 応するものとしないものとの二群に分類できる(表 I)。この成績 は、HEV上のL-セレクチンリガンドが、通常のシアリルルイス xとは異なる糖鎖であり、しかもシアリルルイス $\mathrm{x}$ に近縁の糖鎖 であることを示唆するものであった。また、HEVをシアリダー ゼ処理しても、ほとんど全ての抗ルイスx抗体と反応しないこと も明らかになった。もしHEVに通常のシアリルルイスxが発現し ていたら、これはシアリダーゼ処理によって通常のルイスxに変 
Table I. Reactivity of six anti-sialyl Lewis $x$ antibodies and newly generated anti-sialyl 6-sulfo Lewis $x$ antibodies to human HEV endothelial cells, helper memory $T$ cells, and pure 6- or 6'sulfated Lewis $x$

\begin{tabular}{|c|c|c|c|c|c|c|c|c|}
\hline & \multicolumn{3}{|c|}{$\begin{array}{c}\text { Classical-type } \\
\text { anti-sialyl Lewis x }\end{array}$} & \multicolumn{3}{|c|}{$\begin{array}{c}\text { Variant-type } \\
\text { anti-sialyl Lewis } x\end{array}$} & \multicolumn{2}{|c|}{$\begin{array}{l}\text { Anti-sialyl 6-sulfo } \\
\text { Lewis x }\end{array}$} \\
\hline & SNH-3 & FH-6 & SLEX-1 & $2 \mathrm{H} 5$ & $2 \mathrm{~F} 3$ & $\begin{array}{c}\text { HECA- } \\
452\end{array}$ & G152 & G72* \\
\hline $\begin{array}{l}\text { Reactivity to } \\
\text { HEV endothelial cells }\end{array}$ & - & - & - & + & + & + & + & + \\
\hline $\begin{array}{l}\text { Reactivity to } \\
\text { helper memory } T \text { cells }\end{array}$ & - & - & \pm & + & + & + & + & + \\
\hline $\begin{array}{l}\text { Reactivity to } \\
\text { sialyl 6-sulfo Lewis x }\end{array}$ & - & - & - & + & + & + & + & + \\
\hline $\begin{array}{l}\text { Reactivity to } \\
\text { sialyl 6'-sulfo Lewis X }\end{array}$ & + & - & + & + & + & + & - & - \\
\hline
\end{tabular}

* G72 cross-reacts to sialyl 6-sulfo lactosamine.

which would have been readily detected by the usual anti-Lewis $\mathrm{x}$ antibodies.

Expression of sialyl Lewis $\mathrm{x}$ and/or sialyl Lewis a on vascular endothelial cells other than HEV is controversial. Cultured human umbilical vein endothelial cells, and also the endothelial cells of other origin, usually lack the sialyl Lewis $\mathrm{x}$ or sialyl Lewis a determinant on the surface. Expression of these determinants is not effectively induced by the treatment of cells with inflammatory cytokines such as IL-1 and/or TNF-a, while these stimuli induce significant expression of E-selectin and other cell adhesion molecules on endothelial cells. The carbohydrate determinants have remained virtually undetected in the immunohistochemical examination of inflamed human tissue samples, with rather rare exceptions mainly chronic-type inflammation accompanied by vigorous infiltration of lymphocytes.

We observed significant reactivity of vascular endothelial cells to an anti-sialyl Lewis $\mathrm{x}$ antibody in two animal experimental systems, one of which is a special type of skin inflammation in rats induced by the modulation of complement activity (15), and the other is the ischemia-reperfusion injury model of the heart in rats (16). These two experimental systems are exceptional in that we could detect sialyl Lewis $\mathrm{x}$-like molecules on endothelial cells. In both systems, the sialyl Lewis $\mathrm{x}$-like molecule was detectable only with the $2 \mathrm{H} 5$ antibody, and was not detectable with other well-known anti-sialyl Lewis $\mathrm{x}$ antibodies including CSLEX-1, SNH-3 or FH-6. This again indicated that the sialyl Lewis $\mathrm{x}$-like determinant appearing in these experimental models was significantly different from the usual authentic sialyl Lewis $x$ determinant, which should have been readily detected by the CSLEX-1, SNH-3 and FH-6 anti- 化し、抗ルイスx抗体によって容易に検出されるはずである。 HEV以外の一般血管にシアリルルイスxやシアリルルイス が発現するかどうかについては、まだ研究者間の見解が一致し ていない。ヒト臍帯静脈などに由来する培養血管内皮細胞は、 通常、シアリルルイス $\mathrm{x}$ もアアリルルイス $\mathrm{a} も$ 発現していない。 IL-1 や TNF- $\alpha$ のうな炎症サイトカインで刺激しても、E-セレ クチンやその他の細胞接着分子の発現は誘導できるが、これら 糖鎖の発現はあまりはかばかしく誘導されない。炎症性病変を 免疫組織学的に観察しても、これら糖鎖の発現は、リンパ球浸 潤の強い慢性炎症において、ごくまれに検出されるにとどま る。

動物実験においても、ラットの皮膚炎モデル(15)や心臓の虚 血再潅流実験(16)においては、抗シアリルルイスx抗体で血管内 皮の染色が観察される。これらの実験系は、ともかく HEV以外 の血管内皮細胞にシアリルルイスx様糖鎖が検出されると云う点 では、むしろ例外的である。このシアリルルイスx様糖鎖は、 2H5抗体のみで検出され、他の抗シアリルルイス $\mathrm{x}$ 抗体では検出 されにくい。この成績は、こうしたモデル実験において血管内 皮に出現するシアリルルイスx様糖鎖もまた、通常のシアリルル イスxとは異なる糖鎖であることを示唆する。血管内皮には通常 のシアリルルイスxが出現することはまずなく、血管内皮細胞の L-セレクチンリガンドは、どうやら通常のシアリルルイスxとは 
bodies as well as the $2 \mathrm{H} 5$ antibody. These findings indicated that the genuine sialyl Lewis $\mathrm{x}$ determinant is rarely expressed on vascular endothelial cells, and that the ligand for L-selectin on endothelial cells, if any, must be somehow different from authentic sialyl Lewis $\mathrm{x}$.

\section{Specificity and Cross-Reactivity of Anti-Sialyl Lewis $x$ Monoclonal Antibodies}

With this in mind, we studied the specificity of hithertoknown anti-sialyl Lewis $\mathrm{x}$ monoclonal antibodies against a panel of pure carbohydrate determinants having a structure related to sialyl Lewis $\mathrm{x}$ (17). All anti-sialyl Lewis $\mathrm{x}$ antibodies significantly reacted with the authentic sialyl Lewis $\mathrm{x}$ determinant, and all of them also reacted with the carbohydrate determinant, NeuAc $\alpha 2 \rightarrow 3 \mathrm{Gal} \beta 1 \rightarrow 4$ [Fuc $\alpha 1 \rightarrow 3$ ] GlcNAc $\beta 1 \rightarrow 6 \mathrm{Gal} \beta 1 \rightarrow \mathrm{R}$ (sialyl Lewis $x$ on the GlcNAc $\beta 1 \rightarrow 6 \mathrm{Gal} \beta$ branch), indicating the linkage between the $\beta$-GlcNAc and the second $\beta-G a l$ is not strongly recognized by these antibodies.

These anti-sialyl Lewis $x$ antibodies exhibited various cross-reactivity to the sialyl Lewis x-related structures. The antibodies $2 \mathrm{~F} 3$, HECA-452 and $2 \mathrm{H} 5$ significantly cross-reacted with sialyl Lewis a, having the structure NeuAc $\alpha 2 \rightarrow 3 \mathrm{Gal} \beta 1 \rightarrow 3$ $[$ Fuc $\alpha 1 \rightarrow$ GlcNAc $\beta 1 \rightarrow R$, whereas other antibodies did not. In contrast, the antibodies CSLEX-1, SNH-3 and FH-6 never crossreacted with sialyl Lewis a. The antibodies SNH-3 and FH-6 were found to be heavily cross-reactive even with the VIM-2 ganglioside, with the structure NeuAc $\alpha 2 \rightarrow 3 \mathrm{Gal} \beta 1 \rightarrow$ 4 GlcNAc $\beta 1 \rightarrow 3 \mathrm{Gal} \beta 1 \rightarrow 4$ [Fuc $\alpha 1 \rightarrow 3$ ] GlcNAc $\beta 1 \rightarrow \mathrm{R}$, which lacks the fucose residue at the penultimate $\beta$-GlcNAc moiety.

Hence, these antibodies can be classified into the two groups (Fig. 1). One group (classical-type antibodies) includes the antibodies CSLEX-1, SNH-3 and FH-6, which recognize the type 2 chain backbone, Gal $\beta 1 \rightarrow 4 \mathrm{lcNAc} \beta$, and therefore never cross-react with sialyl Lewis a having the type 1 chain back-
異なるものであると考えられる。

C. 抗シアリルルイスx抗体の特異性と交差反応性

こうした事情から、我々は純品糖鎖を用いてこれらの抗シ アリルルイスx抗体の反応特異性を調べてみることにした(17)。 当然ながら、全ての抗シアリルルイスx抗体が純品シアリルルイ

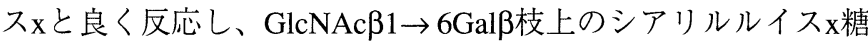
鎖 $($ NeuAc $2 \rightarrow 3$ Gal $\beta 1 \rightarrow 4[$ Fuc $\alpha 1 \rightarrow 3]$ GlcNAc $\beta 1 \rightarrow 6$ Gal $\beta 1 \rightarrow \mathrm{R})$ と

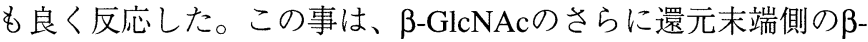
Galは、これらの抗体によってあまり強く認識されていない事を 示す。

抗シアリルルイスx抗体によって、シアリルルイスx類似糖 鎖にたいする交差反応性に大きなちがいが見られた。2F3、 HECA-452、2H5などの抗体はシアリルルイス A 糖鎖NeuAco2 $\rightarrow$ $3 \mathrm{Gal} \beta 1 \rightarrow 3[\mathrm{Fuc} \alpha 1 \rightarrow] \mathrm{GlcNAc} \beta 1 \rightarrow \mathrm{R}$ との交差反応性を示した。他 方、CSLEX-1、SNH-3、FH-6はシアリルルイス $\mathrm{a}$ 糖鎖との交差反 応性を示さない。しかしこのうちSNH-3抗体とFH-6抗体とは、 亜末端のß-GlcNAc がフコシル化されていないVIM-2 ガングリオ シドNeuAc $\alpha 2 \rightarrow 3 \mathrm{Gal} \beta 1 \rightarrow 4 \mathrm{GlcNAc} \beta 1 \rightarrow 3 \mathrm{Gal} \beta 1 \rightarrow 4[\mathrm{Fuc} \alpha 1 \rightarrow 3]$ $\operatorname{GlcNAc} \beta 1 \rightarrow \mathrm{R}$ と強い交差反応性を示した。

この結果から、これらの抗体は図1のような二つのグループ に分類できることが判明した。CSLEX-1、SNH-3、FH-6からなる 古典的な抗シアリルルイスx抗体のグループは、 2 型基幹構造 $\mathrm{Ga} 1 \beta 1 \rightarrow 4 \mathrm{GlcNAc} \beta$ を強く認識し、1 型基幹構造のシアリルルイ ス $\mathrm{a}$ 糖鎖と交差反応性を示さない。これらの抗体のうちでは

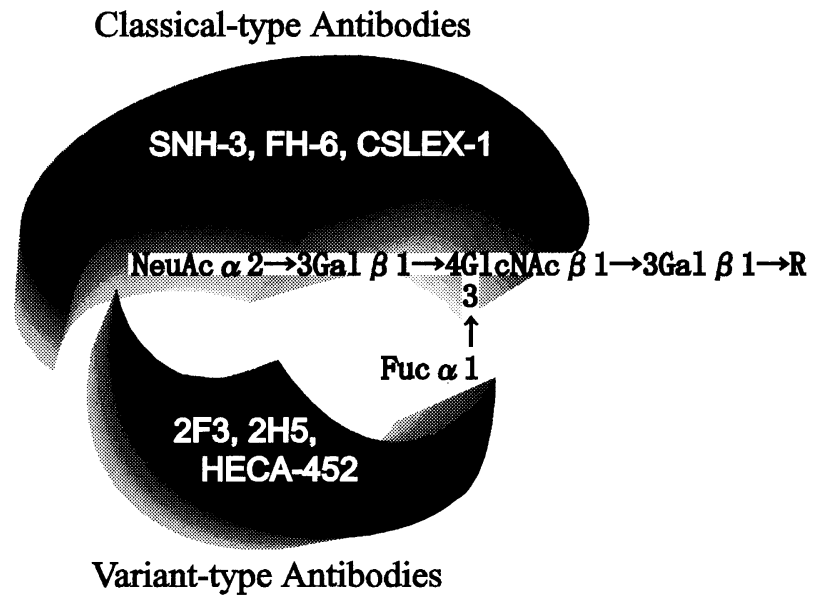

Fig. 1. Schematic representation of the reactivity of two groups of anti-sialyl Lewis $X$ antibodies. 
bone, Gal $\beta 1 \rightarrow 3 \mathrm{GlcNAc} \beta$. Among these antibodies, CSLEX-1 seems to be relatively specific to sialyl Lewis $\mathrm{x}$, while the other two antibodies do not appear to strictly recognize the $\alpha$-Fuc moiety on the penultimate GlcNAc $\beta$, judging from their heavy cross-reactivity against VIM-2 ganglioside.

The other group (variant-type antibodies) includes the antibodies 2F3, HECA-452 and 2H5, which do not recognize the type 2 chain backbone, Gal $\beta 1 \rightarrow 4$ GlcNAc $\beta$, while they recognize terminal $\alpha$-Fuc as well as $\alpha$-NeuAc moieties, and never cross-react with structures devoid of $\alpha$-Fuc moiety on the penultimate $\beta$-GlcNAc.

The ligand for L-selectin on HEV endothelial cells reacts only with the variant group antibodies, and not to the classical group antibodies. This indicates the ligand for L-selectin on HEV endothelial cells could be the sialyl Lewis $x$ determinant modified at the Gal $\beta 1 \rightarrow 4 \mathrm{GlcNAc} \beta$ backbone structure, yet retains terminal $\alpha$-Fuc and $\alpha$-NeuAc moieties. It is easily deduced that the classical group antibodies, which strongly recognize the Gal $\beta 1 \rightarrow 4 \mathrm{GlcNAc} \beta$ backbone, would be very sensitive to the modification at the backbone structure, while the reactivity of the variant group antibodies, which do not recognize the Gal $\beta 1 \rightarrow 4$ GlcNAc $\beta$ backbone, would not be affected by the modification.

\section{Sialyl 6-sulfo Lewis $\mathrm{x}$ as the Major L-Selectin Ligand on HEV}

It has long been known that L-selectin, as well as Pselectin, significantly binds to sulfated carbohydrates such as fucoidin, but E-selectin does not. This led to the hypothesis that sulfated carbohydrate determinants may be a specific ligand for L-selectin on HEV (18-20). The antibody MECA-79, which recognizes still undefined sulfated carbohydrate ligands, strongly labels the HEV endothelial cells irrespective of animal species, and significantly inhibits L-selectin-dependent cell adhesion on HEV endothelial cells. It was therefore a good tool with which to study the L-selectin ligand on HEV. The results of studies using this antibody suggestet that several sulfated sialyl Lewis $\mathrm{x}$ determinants were present on murine HEV endothelial cells $(21,22)$. These included the sialyl Lewis $x$ determinant sulfated at C-6 position of $\beta$-Gal (sialyl 6'-sulfo Lewis $\mathrm{x}$ ) and the sialyl Lewis $x$ determinant sulfated at $\beta$-GlcNAc (sialyl 6-sulfo Lewis $\mathrm{x})$.

Since these modifications occur at the Gal $\beta 1 \rightarrow 4 \mathrm{GlcNAc} \beta$ backbone structure, we thought they could be the determinants that had been specifically recognized by the variant group antibodies in HEV of human lymph nodes, and studied the reactivity of these sulfated compounds against the set of anti-sialyl Lewis $\mathrm{x}$ monoclonal antibodies. The results showed that sialyl 6 '-sulfo Lewis $\mathrm{x}$ was reactive to a wide variety of antibodies including 2F3, 2H5, SNH-3, HECA-452 and CSLEX-1 (8). Only the antibody FH-6 lost its reactivity to sialyl Lewis $\mathrm{x}$ upon the
CSLEX-1が比較的シアリルルイスx糖鎖に特異的であるが、他の 二つの抗体は、VIM-2 ガングリオシドとの交差反応性から、フ コースに対する認識が弱いと考えられた。

一方、2F3、HECA-452、2H5からなるバリアント型抗シアリ ルルイスx抗体のグループは、 2 型基幹構造の認識が甘く、むし ろシアル酸とフコースを強く認識し、亜末端にフコースを欠く 構造とは交差反応が見られない。

HEV上のL-セレクチンリガンドは、バリアント型抗シアリ ルルイスx抗体のグループとのみ反応し、古典的な抗シアリルル イスx抗体のグループとは反応しない。このことから、HEV上の L-セレクチンリガンド糖鎖は、通常のシアリルルイス $\mathrm{x}$ の Gal $\beta 1$ $\rightarrow 4 \mathrm{GlcNAc} \beta$ 部分にさらに修飾が加わったものであり、かつ、シ アル酸とフコースは保たれたような構造である可能性が強く示 唆された。古典的な抗シアリルルイスx抗体のグループは、 Gal $\beta 1 \rightarrow 4 G l c N A c \beta$ 部分を強く認識しており、この部分が修飾さ れると反応性を失うであろうこと容易に推察できる。一方、バ リアント型抗シアリルルイスx抗体のグループの場合には、基幹 のGal $\beta 1 \rightarrow 4 G \mathrm{GlNAc} \beta$ 部分をほとんど認識していないので、この 部分にさらに修飾が起こっても、反応性は大きな影響を受けな いと考えられた。

D. HEV上のL-セレクチンリガンドとしてのシアリル 6 -スルホル イスx

L-セレクチンはP-セレクチンと同様に、フコイジンなどの 硫酸基を持つ糖鎖と良く反応する点が、E-セレクチンと異なる ことが古くから知られていた。このことから、リガンドとして 硫酸基を有する糖鎖に着目する研究の流れが形成された(1820)。この流れの研究では、リガンド研究手段として、MECA-79 抗体が良く用いられてきた。この抗体は構造不明の硫酸化糖鎖 を認識し、動物種を問わずHEVとよく反応し、HEVに対するリ ンパ球のL-セレクチン依存性接着を強く阻害する。これは、Lセレクチンの糖鎖リガンドが硫酸化糖鎖である事を強く支持す る。MECA-79抗体をもちいた研究の結果、マウスリンパ節 $\mathrm{HEV}$ には $\beta-G a l の 6$ 位が硫酸化されたシアリル6'-スルホルイス $\mathrm{x}$ 、お よびß-GlcNAcの 6 位が硫酸化されたシアリル6-スルホルイスxが 存在する可能性を示唆する成績が報告された $(21 、 22)$ 。

これらの糖鎖は、硫酸基でGal $\beta 1 \rightarrow 4 \mathrm{GlcNAc} \beta$ 部分が修飾さ れたシアリルルイスxであるため、我々がヒトHEVの L-セレク チンリガンドの検出に用いた一連の抗シアリルルイス $\mathrm{x}$ 抗体と反 応する可能性が考えられた。そこで純品のシアリル6-スルホル イスxおよびシアリル6'-スルホルイス $\mathrm{x}$ と一連の抗体との反応性 を検討した。その結果、シアリル6'-スルホルイス SNH-3、HECA-452、CSLEX-1など、ほとんどの抗体と反応し、 FH-6のみが $\beta-G a l の ~ 6$ 位が硫酸化によって反応性を失うことがわ かった(表 I)(8)。一方、シアリル6-スルホルイスxは、2F3、2H5、 
6'-sulfation of its $\beta$-Gal moiety (Table I). In contrast, sialyl 6sulfo Lewis $x$ was reactive to the antibodies $2 \mathrm{~F} 3,2 \mathrm{H} 5$, HECA452, but not to SNH-3, FH-6 and CSLEX-1, the very same reaction pattern of HEV in human lymph nodes (Table I) (8).

These findings indicated that the sialyl 6-sulfo Lewis $\mathrm{x}$ determinant, having the structure NeuAc $\alpha 2 \rightarrow 3 \mathrm{Gal} \beta 1 \rightarrow$ $4[\mathrm{Fuc} \alpha 1 \rightarrow 3]\left[\mathrm{SO}_{4}-6\right] \mathrm{GlcNAc} \beta 1 \rightarrow \mathrm{R}$, is a good candidate for the putative ligand for L-selectin on HEV. The inability of most conventional anti-Lewis $\mathrm{x}$ antibodies to sialidase-treated HEV endothelial cells further supported this, since these anti-Lewis $x$ antibodies are not reactive to 6-sulfo Lewis $\mathrm{x}$, yet readily reactive to 6 '-sulfo Lewis $\mathrm{x}$ determinant (9).

On the contrary, sialyl 6'-sulfo Lewis $\mathrm{x}$ determinant cannot be the major component of the L-selectin ligand on human $\mathrm{HEV}$. If so, $\mathrm{HEV}$ endothelial cells should have been reactive to the SNH-3 and CSLEX-1 antibodies, as well as 2H5, 2F3 and HECA-452. They should have been reactive to most of the antiLewis $\mathrm{x}$ antibodies as well, after sialidase treatment.

We subsequently generated a monoclonal antibody, G152, specifically directed to sialyl 6-sulfo Lewis x determinant (9). This antibody is reactive only to the sialyl 6-sulfo Lewis $\mathrm{x}$ determinant, and not to the sialyl 6'-sulfo Lewis $\mathrm{x}$ - or genuine sialyl Lewis $\mathrm{x}$ determinants. The antibody strongly stained HEV endothelial cells in human peripheral lymph nodes and nearly completely inhibited the binding of recombinant L-selectin to the HEV endothelial cells (9). We have also generated several antibodies directed to 6-sulfo Lewis $\mathrm{x}$ determinant, which do not cross-react to 6'-sulfo Lewis $\mathrm{x}$ or conventional Lewis $\mathrm{x}$ determinant. These antibodies clearly labeled HEV endothelial cells after sialidase treatment. These findings confirmed that the sialyl 6-sulfo Lewis $\mathrm{x}$ determinant is significantly expressed, and serves as a major ligand for L-selectin on HEV endothelial cells.

Our conclusion is in line with the observation of the substrate specificity of Fuc-T VII (23), which indicated that the enzyme can act on the $\beta$-GlcNAc-sulfated substrate, thus preferentially producing sialyl 6 -sulfated Lewis $\mathrm{x}$, while it could not utilize the $\beta$-Gal-sulfated oligosaccharide as substrate, and probably does not contribute to the direct production of sialyl 6'sulfo Lewis x. From their examination of the substrate specificity of a sulfotransferase which transfers sulfate residues to the C-6 position of the $\beta$-Gal moiety, Habuchi et al. concluded that the enzyme worked much less efficiently when the $\beta$-GlcNAc moiety was not pre-sulfated (24). This suggests that the 6'sulfation at $\beta \mathrm{Gal}$ mainly occurs after the 6 -sulfation of the $\beta$ GlcNAc moiety.

Thus, our results are at variance with a report (25) that, whereas sialyl 6'-sulfo Lewis $\mathrm{x}$ is reactive to L-selectin, sialyl 6sulfo Lewis $\mathrm{x}$ is not. Our results are also different from a report of the exact opposite results, namely that recombinant L-selectin binds to sialyl 6-sulfo Lewis $\mathrm{x}$, but not to sialyl 6'-sulfo Lewis $\mathrm{x}$ in ELISA (26). In assays using recombinant L-selectin, the sialyl
HECA-452 と反応し、SNH-3、FH-6、CSLEX-1 と反応しないとい う点で、HEVと全く同じ反応のパターンを示した(表 I)(8)。

このことから、NeuAc $\alpha 2 \rightarrow 3 \mathrm{Gal} \beta 1 \rightarrow 4[\mathrm{Fuc} \alpha 1 \rightarrow 3]\left[\mathrm{SO}_{4}-6\right]$ GlcNAc $\beta 1 \rightarrow \mathrm{R}$ の構造を有するシアリル6-スルホルイス xが、HEV 上のL-セレクチンリガンドである可能性が高いと考えられた。 また、通常の抗ルイスx抗体のほとんどはシアリダーゼ処理HEV と反応しないが、6-スルホルイスxもこれらの抗体とは反応しな い。他方、6'-スルホルイスxは、これら通常の抗ルイスx抗体と 良く反応する。この所見も、シアリル6-スルホルイスxが、HEV 上のL-セレクチンリガンドであることをさらに支持する成績と 考えられた(9)。

一方、シアリル6'-スルホルイスxがHEV上のL-セレクチンリ ガンドである可能性はきわめて低いと判断せざるを得ない。も しそうであったら、SNH-3 PCSLEX-1抗体は2H5、2F3、HECA452 と同様にHEVと良く反応したはずであり、またシアリダーゼ 処理HEVはほとんど全ての抗ルイスx抗体と反応したはずだから である。

次に我々は、シアリル6-スルホルイスxに特異的な単クロー ン抗体G152を作成した(9)。この抗体は、シアリル6-スルホルイ スxとのみ反応し、シアリル6'-スルホルイス $\mathrm{x}$ や通常のシアリル ルイスxとは交差しない。この抗体G152はリンパ節HEVときわ めて強く反応し、リコンビナントL-セレクチンのヒトリンパ節 凍結切片上のHEVへの結合をも阻止する $(9)$ 。また我々は、6-ス ルホルイスxに特異的な一連の抗体を新たに作成した。これらの 抗体は、6-スルホルイス $\mathrm{x}$ との反応し、6'-スルホルイスxや通 常のルイスxとは交差しない。この抗体はシアリダーゼ処理後の リンパ節HEVときわめて強く反応した。これらの所見から、シ アリル6-スルホルイスxがヒトHEV上に強く発現され、L-セレク チンの糖鎖リガンドとなっていることがさらに確認された。

我々のこの結論は、フコシルトランスフェラーゼFuc-TVII が、 $\beta$-GlcNAcの 6 位が硫酸化された基質にはたらいてシアリル

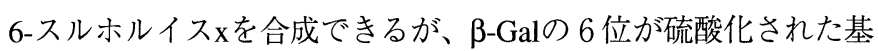
質に対しては働かず、シアリル6'-スルホルイス $\mathrm{x}$ 合成できない とする報告(23)と良く一致する。またHabuchiらは、 $\beta$-Galの 6 位 を硫酸化するスルホトランスフェラーゼの特異性を調べ、隣の $\beta$-GlcNAcの 6 位が硫酸化された基質に対してはよく働くが、 $\beta$ GlcNAcが硫酸化されていない場合には活性が低いことを報告し た。このことは、 $\beta-G a l の 6$ 位の硫酸化が、 $\beta-\mathrm{GlcNAc} の 6$ 位の硫 酸化のあとに起こることを示唆している(24)。

一方、リコンビナントL-セレクチンとの結合をin vitroで見 た実験結果では、シアリル6'-スルホルイスxは結合するがシアリ ル6-スルホルイスxは結合しないとする研究者もいる(25)。これ は我々の得ていた結論と反対である。また、逆にリコンビナン トL-セレクチンはシアリル6-スルホルイスxには結合するがシア リル6'-スルホルイスxには結合しないとする研究者もいる(26)。 これも我々の得た結果とは異なる。In vitroで見る限りでは、リ 
Trends in Glycoscience and Glycotechnology Vol.11 No.62 ((November 1999) pp.329-344

6-sulfo Lewis $x$ and sialyl 6'-sulfo Lewis $x$ determinants are both reactive to L-selectin in our hands as reported previously by Yoshino et al. (27). What we wish to emphasize is that the sialyl 6 '-sulfo Lewis $x$ determinant is so far not detectable as far as human lymph nodes are concerned, and that only the sialyl 6sulfo Lewis $\mathrm{x}$ determinant seems to be present and serves as a major L-selectin ligand in HEV of human peripheral lymph nodes.

\section{E. Reconstitution of L-Selectin Ligand by Transfection of Fucosyltransferase and Sulfotransferase}

The sialyl 6-sulfo Lewis $\mathrm{x}$ determinant must be synthesized through the concerted action of a GlcNAc $\beta$ : $6-O$ sulfotransferase (6-Sul-T) and a fucosyltransferase. More recently, we obtained a cDNA clone which encodes a sulfotransferase (28), and succeeded in reconstituting functional L-selectin ligands on COS-7 cells or a cultured human endothelial cell line ECV304 by transfecting the $\alpha 1 \rightarrow 3$ fucosyltranseferase VII (Fuc-T VII) and/or the cloned 6-Sul-T cDNAs (10) (Fig. 2).

The ECV304 cells were reportedly established from human umbilical vein endothelial cells (29), and lacked the expression of sialyl 6-sulfo Lewis $\mathrm{x}$, conventional Lewis $\mathrm{x}$, and Lselectin ligand activity. When the cells were transfected with Fuc-T VII, conventional sialyl Lewis $\mathrm{x}$ appeared at the cell surface, but the transfectant cells did not adhere to the cells expressing L-selectin (Fig. 2), indicating conventional sialyl Lewis $\mathrm{x}$ was not sufficient to confer L-selectin mediated cell adhesion. When the cells were transfected with 6-Sul-T, sialyl 6-sulfo lactosamine appeared on the cell surface, but the transfectant cells did not adhere to the cells expressing L-selectin (Fig. 2). Interestingly, a significant reactivity to the MECA-79 antibody appeared on the transfectant cells. MECA-79 antibody was originally raised against murine lymph node stroma, and has long been used to detect L-selectin ligand on HEV endothelial cells, since the antibody strongly stains the cells, and inhibits Lselectin-mediated adhesion on HEV endothelial cells. It has been suggested that the antigen recognized by this antibody is sulfation-dependent, but not dependent on sialic acid or fucose. Thus this antibody recognizes products of 6-Sul-T, but the 6sulfation per se was not sufficient to confer L-selectin mediated cell adhesion.

The sialyl 6-sulfo Lewis $\mathrm{x}$ determinant as detected by the G152 antibody appeared only on the ECV304 cells doubly transfected with Fuc-T VII and 6-Sul-T, and only these double transfectant cells showed significant adhesion of cells expressing L-selectin (Fig. 2) (10). Reactivity of the doubly transfected cells against anti-sialyl Lewis $\mathrm{x}$ antibodies such as $\mathrm{SNH}-3$, FH6 and CSLEX-1 was significantly suppressed, while these antibodies strongly reacted to the Fuc-T VII single transfectant cells. In contrast, reactivity of the antibodies $2 \mathrm{~F} 3,2 \mathrm{H} 5$ and HECA-
コンビナントL-セレクチンは、シアリル6'-スルホルイスxにもシ アリル6-スルホルイスxにも結合する。この点は以前にYoshino ら(27)が報告したとおりである。我々が強調したい点は、実際に 糖鎖リガンドが発現しているはずのヒトリンパ節HEVにおい て、シアリル6-スルホルイスxが発現して主要な内在性のリガン ドとなっている証拠は得られるが、シアリル6'-スルホルイスxは 検出されなかったという点である。

E. フコシルトランスフェラーゼおよびスルホトランスフェラー ゼCDNAのトランスフェクションによるL-セレクチン糖鎖リガン ドの再構成

シアリル6-スルホルイス $\mathrm{x}$ の合成には、フコシルトランス フェラーゼ(Fuc-T)とGlcNAcß: 6-O-スルホトランスフェラーゼ(6Sul-T) が関与すると考えられる。我々はフコシルトランスフェ ラーゼ Fuc-TVII と、最近得られた 6-Sul-TのcDNA(28)を同時に あるいはそれぞれ単独にCOS-7 細胞やヒト血管内皮細胞株 ECV304 に導入して、これに対するL-セレクチン発現細胞の接着 を観察した(10) (図 2)。

ECV304 細胞は、HUVECから樹立したとされ(29)、シアリ ル6-スルホルイス $\mathrm{x}$ 通常のシアリルルイス $\mathrm{x}$ 発現せず、L-セ レクチンにも接着しない。これにFuc-TVIIのみを単独導入した 細胞は、シアリルルイス $\mathrm{x}$ 強く発現し、2H5抗体と反応する が、L-セレクチンへの接着は観察されない(図2)。シアリルルイ スxを発現するだけでは、L-セレクチンとの結合には十分でない ことが判明した。また、6-Sul-Tのみを単独導入した細胞では、 6-スルホラクトサミンを強く発現するが、これもL-セレクチン への接着は観察されない(図 2)。ただし、このトランスフェク夕 ントは、MECA-79抗体と反応するようになった。MECA-79抗体 はマウスリンパ節ストローマを免疫して得られた抗体であり、 HEVと強く反応し、L-セレクチン依存性接着を阻止することか ら、HEV上のL-セレクチンリガンドの検出に良く使われてき た。この抗体の認識抗原は硫酸化糖鎖で、シアル酸やフコース は抗体の反応性には関与していないとされていた。このトラン スフェクタント細胞がMECA-79と反応するようになったこと は、この抗体の認識糖鎖が、6-Sul-Tの反応産物である事を示し ている。ただし、この抗体の認識糖鎖の出現のみでは、L-セレ クチンとの結合には十分でないことも明らかになった。

ECV304 細胞に 6-Sul-TとFuc-TVII とをダブルトランスフェ クトすると、はじめてシアリル6-スルホルイスxが細胞表層に発 現し、L-セレクチンとの接着能が誘導された(図2)(10)。ダブル トランスフェクトした細胞は、SNH-3、FH-6、CSLEX-1抗体との 反応性がFuc-TVII単独トランスフェクタント細胞に比べて低下 した。一方、2F3、2H5、HECA-452抗体との反応性には差が見ら れなかった。このことから、ダブルトランスフェクト細胞に は、シアリル6-スルホルイスxが強く発現し、通常のシアリルル イスxは抑制されていると考えられた。 


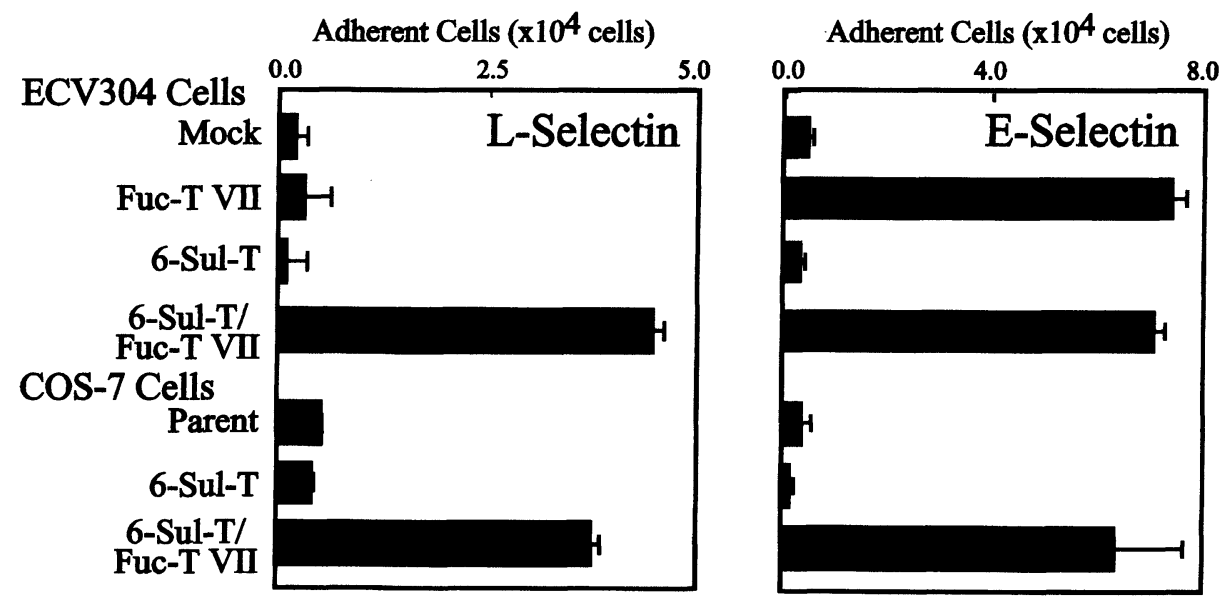

Fig. 2. Binding of L- and E-selectin-expressing cells to ECV304 and COS-7 cells transfected with fucosyltransferase VII (Fuc-T VII) and/or GlcNAc $\beta$ : 6-sulfotransferase (6-Sul-T) cDNAs.

452 to the double transfectant cells was not altered compared to that against Fuc-T VII single transfectant cells. In other words, the doubly transfected cells mainly express sialyl 6-sulfo Lewis $\mathrm{x}$, but a much smaller amount of conventional sialyl Lewis $\mathrm{x}$.

Essentially the same results were obtained by the transfection of these cDNAs to COS-7 cells (Fig. 2). The COS-7 cells transfected with Fuc-T VII cDNA expressed conventional sialyl Lewis $\mathrm{x}$ but not sialyl 6-sulfo Lewis $\mathrm{x}$, and the cells transfected with 6-Sul-T cDNA expressed sialyl 6-sulfo lactosamine but not sialyl 6-sulfo Lewis $\mathrm{x}$. The sialyl 6-sulfo Lewis $\mathrm{x}$ appeared only on the COS-7 cells transfected by cDNAs of both enzymes, and only these cells conferred L-selectin-mediated cell adhesion. The only difference between ECV304 and COS-7 transfectant cells was that the MECA-79-defined epitope appeared on the 6-Sul-T-transfected ECV304 cells but not on the 6-Sul-T-transfected COS-7 cells. This suggested the need for additional factor (s) for the expression of MECA-79 epitope in addition to 6-Sul-T, which was present in ECV304 but not in COS-7 cells.

\section{F. Roles of Core Proteins in Selectin Mediated Cell Adhe- sion}

The above-described findings further confirmed that sialyl 6-sulfo Lewis $x$ is a preferred ligand for L-selectin. The experiments also indicated interesting differences among the binding specificity of the three selectins. L-selectin bound only to the cells doubly transfected with Fuc-T VII and 6-Sul-T, which express sialyl 6-sulfo Lewis $\mathrm{x}$. On the other hand, cells expressing E-selectin strongly adhered to the Fuc-T VII single transfectant cells as well as the doubly transfected cells, again confirming that E-selectin requires only the sialyl Lewis $\mathrm{x}$ structure for binding (10). Unexpectedly, P-selectin failed to show significant bind-
COS-7細胞を用いた実験からも、ほほ同様の結果が得られ た(図2)。すなわち、これにFuc-TVIIのみを単独導入した細胞 は、通常のシアリルルイスxを強く発現するがシアリル6-スルホ ルイスxは発現せず、6-Sul-Tのみを単独導入したCOS-7細胞で は、6-スルホラクトサミンを強く発現するが、シアリル6-スル ホルイスxは発現しない。シアリル6-スルホルイスxは6-Sul-Tと Fuc-TVIIとをダブルトランスフェクトすると、はじめて発現 し、この細胞にのみL-セレクチンとの接着能が誘導された(図 2) (10)。ECV304細胞とCOS-7細胞との違いは、6-Sul-Tを導入した ECV304細胞ではMECA-79の認識抗原が出現したのに、6-Sul-T を導入したCOS-7細胞には出現しなかったことである。このこ とは、MECA-79の認識抗原の発現には、6-Sul-Tに加えてさらに ほかの要因が必要であり、これがECV304細胞には備わってい たが、COS-7細胞には欠如していたことを示唆する。

F. セレクチンを介した細胞接着における糖鎖のコアタンパク質 の役割

以上の結果から、シアリル6-スルホルイスxがL-セレクチン の糖鎖リガンドであることが確認された。この再構成実験に よって、三つのセレクチンが、それぞれ異なるリガンド特異性 を持つことが明らかになった。L-セレクチンは6-Sul-TとFucTVIIとをダブルトランスフェクトした細胞のみに結合したが、 E-セレクチンはFuc-TVIIを単独導入した細胞と、Fuc-TVII と6Sul-Tをダブルトランスフェクトした細胞に対してよく接着した (10)。これにより、従来から主張されているとおり、E-セレク チンにとっては、シアリルルイスx糖鎖が存在するだけで十分 である事が判明した。他方、P-セレクチンは、ダブルトランス フェクトを含め、いずれの細胞にも有意の接着が認められな かった (10)。これは、ECV304細胞やCOS-7細胞に、P-セレクチ 
ing to any of these transfectant cells including the doubly transfected ones (10). This suggested that the core protein PSGL-1 was specifically required for P-selectin, since the ECV304 and COS-7 cells both lacked the expression of PSGL-1.

These findings shed light on the significance of core proteins, which have been supposed to optimize L-selectin ligand activity. The above-mentioned results indicate that just the cotransfection of two glycosyltransferase cDNAs suffices to make cells adherent to L-selectin, yet not to P-selectin. This finding on the cells, which express identical profiles of carbohydrates, argues strongly that the protein backbone requirements of at least these two selectins are quite distinct.

Several specific core proteins proposed for L-selectin ligands to date include GlyCAM-1, CD34, Sgp150/>200, and more recently, podocalyxin (30-33). However, as yet there is no definitive evidence to support an absolute requirement for a specific core protein for the L-selectin ligand activity. GlyCAM-1 has not been described for humans yet; it seems to be a rodentspecific protein, and the ECV304 or COS-7 cells lacked glycoproteins with the same molecular weight range as GlyCAM-1. Lymphocyte homing is reportedly not impaired in CD34 knockout mice (34). PSGL-1, originally described as a specific core protein for $\mathrm{P}$-selectin, was found to be also required for the high affinity binding of L-selectin (14,35-37). Since endothelial cells generally lack expression of PSGL-1, this must be limited to the L-selectin mediated leukocyte-leukocyte interaction, and may not be involved in the L-selectin mediated leukocyte-endothelial cell interaction. The ECV304 and COS-7 cells also did not express CD34 and PSGL-1, but still adhered to L-selectin. Lack of the hitherto-proposed specific core proteins in the ECV304 cells is a compelling argument against the absolute requirement for these core proteins in L-selectin-mediated cell adhesion. Even the transfection of COS-7 cells, which are generally assumed to lack such specific core proteins, with glycosyltransferase genes generated the L-selectin ligand activity.

One must mention here a certain ambiguity that has consistently remained in the discussion of the biological significance of core proteins for selectin ligands. Most researchers agree on the importance of carbohydrate determinants in ligands for three selectins. We know that these determinants in any case need supporting molecules to be expressed on cell membranes with a certain density and in appropriate conformation. In this sense, there is no way of denying the requirement of protein backbones to optimize ligand activity. However, we think some evidence indicating the specific recognition of a particular portion of the concerned peptide backbone by selectins would be needed, before one may call the protein a specific core protein. The sulfated tyrosine residues in PSGL-1 for P-selectin would be a case in point. Otherwise, a core protein may indirectly affect the binding activity to some extent, but it would be easy to find other similar surrogate (substitute) proteins, and such a
ンとの結合に必要なPSGL-1ないしはそれに代替できるコアタン パク質が存在しなかったためと考えられる。

この再構成実験はL-セレクチンのリガンド分子の糖鎖部分 と、その糖鎖を担うコアタンパク質の意義について、面白い問 題を投げかけている。この実験結果は、二種の糖転移酵素cDNA のトランスフェクションによって、L-セレクチンとの結合能は 再構成できるが、P-セレクチンの結合能は再構成できないこと を示す。このことから、L-セレクチンとP-セレクチンとでは、 コアタンパク質に対する要求性が異なることがわかる。

これまでに、GlyCAM-1、CD34、Sgp150/>200、ポドカリキ シンなどがHEVにおけるL-セレクチンの特異的コアタンパク質 として記載されている(30-33)。しかし、L-セレクチンを介した 接着に、これらのタンパク質うちどれかが必須であるという証 拠はない。GlyCAM-1は、マウスで報告されているが、ヒトには 存在が報告されていない。CD34ノックアウトマウスで、特にリ ンパ球のホーミングの異常は記載されていないようである(34)。 ECV304細胞もCOS-7細胞も、GlyCAM-1を欠き、CD34も発現し ていない。それにもかかわらず、トランスフェクタント細胞に は有意のL-セレクチンへの接着が観察できる。PSGL-1は、はじ めP-セレクチンの特異的コアタンパク質として報告されたが、 L-セレクチンを介した接着でも必須とされるようになった(14、 35-37)。通常、血管内皮細胞にはPSGL-1は発現されていないか ら、PSGL-1は白血球-白血球相互作用に関与しているのであろ う。ECV304細胞やCOS-7細胞にも、PSGL-1は発現されていな い。このように、我々が実験に使った細胞には、これまでに報 告されたL-セレクチンのコアタンパク質が存在しないのに、糖 転移酵素および硫酸基転移酵素のトランスフェクションだけで L-セレクチンへの有意の結合が見られたわけである。L-セレク チンとの結合においては、コアタンパク質はあまり重要な意義 をもっていないことを示唆する所見であると思われる。

セレクチンの糖鎖りガンドのコアタンパク質についての議 論には、常にある種のあいまいさが伴っている。セレクチンの リガンドとして糖鎖が重要であることはだれしも否定しない。 糖鎖が細胞膜上にちょうど良い密度やコンフォーメーションで 発現されるには、ともかく支持分子として何らかのムチン様夕 ンパク質が必要である。この意味では、コアタンパク質の必要 性は否定できない。しかし、そのタンパク質が「特異的コアタ ンパク質」と呼ばれる資格があるのは、そのタンパク質のペプ チド部分のどこかにセレクチンによって特異的に認識される部 分がある場合ではなかろうか。P-セレクチンに対するPSGL-1の 硫酸化チロシン残基が好例である。そうでない場合には、コア タンパク質は、ほかの類似タンパク質でいくらでも代替えが可 能な、単なるムチン型糖鎖の担体に過ぎないものであり、その 細胞接着への影響も、糖鎖の密度などを通した間接的影響にと 
protein would not qualify as a specific core protein.

Moreover, there is no published research suggesting that up- or down-regulation of the hitherto-described core proteins would regulate L-selectin ligand activity at the surface of cells under physiological conditions. In contrast, Fuc-T VII, which is supposed to be involved in the synthesis of L-selectin ligand in endothelial cells, is quite actively regulated transcriptionally. Recently, we have shown that the enzymatic activity of 6-Sul-T is subject to the regulation mediated by cytokines such as IL-1, though not so pronounced as Fuc-T VII (10).

\section{G. Synthesis of Sialyl 6-Sulfo Lewis $x$ in Endothelial Cells, Leukocytes and Epithelial Cells}

Molecular cloning of cDNA for the 6-Sul-T responsible for the synthesis of sialyl 6-sulfo Lewis $\mathrm{x}$ was first reported by Uchimura $e t$ al. for both murine and humans $(28,38)$. The message of this isozyme is significantly expressed in HEV, and several other organs including brain, placenta, spleen and bone marrow $(28,38,39)$. This isozyme was shown to be able to synthesize both sialyl 6-sulfo Lewis $\mathrm{x}$ and MECA-79-defined epitope (10). This enzyme incorporates 6-sulfo residues into $\mathrm{O}$-glycan precursors as well as $\mathrm{N}$-linked glycan precursors, and of course into keratan sulfate precursors. It seems to prefer $O$ glycan precursors to $N$-linked glycan precursors. More recently Bistrup et al. (40) reported another human 6-Sul-T isozyme, which is more strictly localized in HEV. The ability of this enzyme to synthesize sialyl 6-sulfo Lewis $\mathrm{x}$ was ascertained by the induction of G72 antibody-defined epitope on transfected cells (40). Later a murine version of this isozyme was also reported (41). Both isozymes are known to be expressed on HEV, and at this writing no definitive information is available as to whether both or only one of these isozymes is responsible for sialyl 6-sulfo Lewis $\mathrm{x}$ expression in HEV endothelial cells.

Since the expression of the MECA-79-defined epitope is strictly confined to HEV endothelial cells, the MECA-79-defined L-selectin ligand has been thought to be synthesized by HEV-specific enzyme(s). Expression of sialyl 6-sulfo Lewis x is, however, not restricted to HEV endothelial cells. The sialyl 6-sulfo Lewis x determinant is also expressed on leukocytes, such as helper memory T cells, NK cells, monocytes, and weakly on granulocytes. The determinant may have some role in Lselectin-mediated leukocyte-leukocyte interactions in these cells. Since sialyl 6-sulfo Lewis $\mathrm{x}$ can bind to E-selectin as well as conventional sialyl Lewis $\mathrm{x}$, the determinant expressed on these leukocyte populations would also bind to E-selectin. We were able to demonstrate in a preliminary study that sialyl 6-sulfo Lewis $\mathrm{x}$ can also serve as a ligand for P-selectin, when leukemic cells expressing PSGL-1 were used for cell adhesion experiments. Sialyl 6-sulfo Lewis $x$ on leukocytes may serve as ligand for all three selectins. It is not clear which isozyme of 6-Sul-T is responsible for the synthesis of sialyl 6-sulfo Lewis $\mathrm{x}$ in leu-
どまるであろう。こうしたものには、とても「特異的」コアタ ンパク質の名を冠することはできないように思われる。

さらに、L-セレクチンとの結合能が、コアタンパク質の アップあるいはダウンレギュレーションによって生理的に調節 されているという証拠もいまのところ知られていない。これに 反して、糖鎖部分については、血管内皮のL-セレクチンリガン ドの合成に関与するとされるFuc-TVIIが活発な転写調節を受け ていることは良く知られているし、最近我々は、Fuc-TVIIほど 著明にではないが、6-Sul-TもまたIL-1などの炎症性サイトカイ ンによって調節されることを見出している $(10)$ 。

G. 血管内皮細胞、白血球および上皮細胞におけるシアリル6-ス ルホルイスメの合成

シアリル6-スルホルイス $\mathrm{x}$ の合成に関与するマウスおよびヒ トの6-Sul-TのcDNAクローニングは、はじめUchimuraらによっ て報告された $(28 、 38)$ 。この酵素はHEV以外にも、脳や胎盤、脾

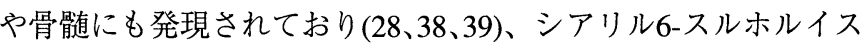
$\mathrm{x}$ の合成やMECA-79認識抗原の合成を行うことが明らかになっ ている(10)。O-グリコシド糖鎖のみならず、 $N$-グリコシド糖鎖 やケラタン硫酸の合成前駆体を基質としてはたらき、 $N$-グリコ シド糖鎖よりも、O-グリコシド糖鎖をより活発に硫酸化するこ とが知られる。また最近、Bistrup ら(40)は、もうひとつ6-Sul-T のアイソザイムを報告した。HEVに局在し、やはりシアリル6スルホルイス $\mathrm{x}$ の合成能を持つことが、トランスフェクション細 胞のG72抗体との反応性から明らかになっている(40)。遅れて、 同じ酵素のマウス版も報告されている(41)。以上の二つのアイソ ザイムは、いずれもHEVに発現しているとされ、これらの両方 か、あるいはどちらか片方がHEVのシアリル6-スルホルイスxの 合成に関与するのか、現時点ではまだ明らかでない。

MECA-79抗体は、高いHEV特異性を持ち、HEVの血管内皮 細胞と強く反応するが、一般血管の内皮細胞とはほとんど反応 しない。また、血管内皮細胞以外の組織・細胞との反応もほと んど報告されていない。このため、この抗体が認識する硫酸化 糖鎖は、HEVに特異的に存在する糖鎖であり、その合成に関与 するスルホトランスフェラーゼもまた、HEVにきわめて特異的 な酵素であるにちがいないと考えられてきた。しかし、シアリ ル6-スルホルイスxの発現は、HEVには限定されていない。シア リル6-スルホルイス $\mathrm{x}$ は白血球の一部、すなわちへルパーメモ リーT細胞、NK細胞、単球、および、弱いけれども顆粒球にも 発現されている。白血球では、シアリル6-スルホルイスxは、Lセレクチン依存性の白血球-白血球相互作用に関与しているので あろう。またシアリル6-スルホルイスxは、E-およびP-セレクチ ンとも結合するので、白血球のシアリル6-スルホルイスxは、Eセレクチンのリガンドとしても機能するであろう。また我々 は、PSGL-1を発現するような白血球系細胞では、シアリル6-ス ルホルイスxは、P-セレクチンとも結合することを見出した。こ のように、白血球系細胞では、シアリル6-スルホルイスxは、三 者の全てのセレクチンのリガンドとして働く可能性がある。白 血球でシアリル6-スルホルイスxの合成に関与するスルホトラン 
kocytes as the transcripts of both isozymes were detected in leukemic cell lines in our preliminary experiments.

Sialyl 6-sulfo Lewis $\mathrm{x}$ is also expressed even on some epithelial cells and several cultured epithelial cancer cells. This may be synthesized through the action of the most-recently described third isozyme of 6-Sul-T, which is reportedly expressed preferentially in the intestine (42). When colon cancer tissues were investigated, normal colonic epithelia were found to express the determinant, while the cancer cells tended to be largely negative. This was in clear contrast to the preferential expression of conventional, non-sulfated sialyl Lewis $\mathrm{x}$ in cancer cells compared to non-malignant colonic epithelium, and suggested the occurrence of significant down-regulation of 6-sulfation upon malignant transformation of colonic cells. Decreased sulfation and increased sialylation have long been known to occur upon malignant transformation of colonic tissues, and these findings are in line with the classical notion.

Our preliminary cell transfection experiments indicated that Fuc-T VII has an ability to synthesize sialyl 6-sulfo Lewis $\mathrm{x}$, while Fuc-T VI can synthesize sialyl 6-sulfo Lewis $\mathrm{x}$ and 6sulfo Lewis $\mathrm{x}$, and Fuc-T IV synthesizes only 6-sulfo Lewis $\mathrm{x}$ among the isozymes of fucosyltransferases. These findings are compatible with the known specificity of these enzymes for nonsulfated substrates. The sialyl 6-sulfo Lewis x determinant in endothelial cells and leukocytes must be synthesized mainly by Fuc- T VII. Since sulfated type 2 chain determinants seemed to be poor substrates for Fuc-T III, Fuc-T VI may play a major role in the synthesis of the sialyl 6-sulfo Lewis $\mathrm{x}$ determinant in epithelial cells.

It has long been a difficult task to assay the enzymatic activity of 6-Sul-T. Internal GlcNAc $\beta$ residues in the substrate oligosaccharides are not efficiently 6 -sulfated by the enzyme under in vitro conditions. It was only in 1996 that this enzyme was shown to require the substrate GlcNAc $\beta$ residue to be located at the non-reducing end of acceptor oligosaccharides (43). The galactosyltransferase which acts on the resulting 6-sulfo GlcNAc $\beta$ residue is proposed to be a distinct enzyme different from conventional galactosyltransferases $(44,45)$. These findings, together with known specificities of fucosyltransferase isozymes, suggest that sialyl 6-sulfo Lewis $\mathrm{x}$ is synthesized through the sequence illustrated in Fig. 3.

\section{H. Distinct Metabolic Pathway of Sialyl 6-Sulfo Lewis x In- volving Cyclic Sialic Acid}

During the course of study of sialyl 6-sulfo Lewis x expressed on human peripheral blood leukocytes, we noticed that expression of the determinant is very unstable upon manipulation of cells. We soon obtained several lines of evidence indicating that sialyl 6-sulfo Lewis $\mathrm{x}$ on leukocytes is rapidly metabolized through a distinct and previously-unknown pathway. The hypothetical metabolic pathway consists of three metabo-
スフェラーゼは、まだわかっていない。上記の二つのアイソザ イムは両方とも白血球系細胞に発現しているようである。

一部の上皮性細胞や培養癌細胞株にも、シアリル6-スルホ ルイスxが発現されている。これらは抢そらく、つい最近記載さ れた、消化管に良く出現するとされるスルホトランスフェラー ゼ(42)によって合成されるのであろう。大腸癌で調べると、癌周 囲の非癌上皮細胞にはしばしばシアリル6-スルホルイスxが発現 されているのに、癌細胞には陰性であることが多い。通常のシ アリルルイスxが、癌に多く、非癌部に少ないのと良い対照をな す。細胞のがん化にともなって、6-硫酸化が低下すると考えら れる。古くから大腸癌では、非癌上皮細胞にはスルホムチンが 多いのに対し、癌細胞ではシアロムチンが増量することが知ら れていたが、この 6 -硫酸化の変化は、この古くからの概念に良 く一致する。

我々は、フコシルトランスフェラーゼのトランスフェク ション実験から、Fuc-TVIIはシアリル6-スルホルイスxの合成能 を持ち、Fuc-TVIはシアリル6-スルホルイスxとアシアロ体の6-ス ルホルイスxを合成し、Fuc-TIVは6-スルホルイスxの合成能を持 つことを見出した。これらの結果は、これまでに知られたこれ らフコシルトランスフェラーゼの基質特異性と合致している。 血管内皮細胞と白血球系細胞のシアリル6-スルホルイスxは主に Fuc-TVIIによって合成されると思われる。また、Fuc-TIIIは、6硫酸化された 2 型糖鎖に対しては働きにくいとみられるので、 上皮性細胞のシアリル6-スルホルイスxは、主としてFuc-TVIに よって合成されると考えられる。

もともと、ラクトサミンのGlcNAcの6位を硫酸化する6-スル ホトランスフェラーゼは、その酵素活性の測定すら困難であっ た。この酵素が、基質としてGlcNAcが非還元末端に露出している ことを要求するとわかってきたのは、ようやく1996年になってか らである(43)。こうして生じた6-スルホGlcNAc末端にガラクトー スを転移して6-スルホラクトサミンを合成するガラクトシルト ランスフェラーゼも、通常のガラクトシルトランスフェラーゼ

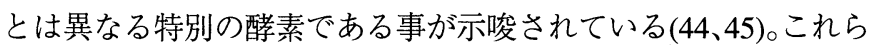
の報告は、まずポリラクトサミン基幹の合成時に6-硫酸化とガラ クトースの付加が起こり、そのあとシアル酸の転移が行われ、 最後にフコシルトラン゙スフェラーゼによってシアリル6-スルホ ルイスxが生じるという合成系路(図 3)が、現在のところは妥当な 考え方である事を示唆する。

H. シアル酸の環状化によるシアリル6-スルホルイスxのユニーク な不活化代謝経路

白血球におけるシアリル6-スルホルイス $\mathrm{x}$ の研究の過程で、 我々はこの糖鎖の発現がきわめて不安定で、細胞を操作するこ とにより容易に消失することを見出した。のちになって、これ

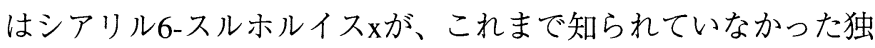
特の経路で代謝されるためであることが判明した。この経路は、 図4に示すように、シアリル6-スルホルイスxのシアル酸残基を 


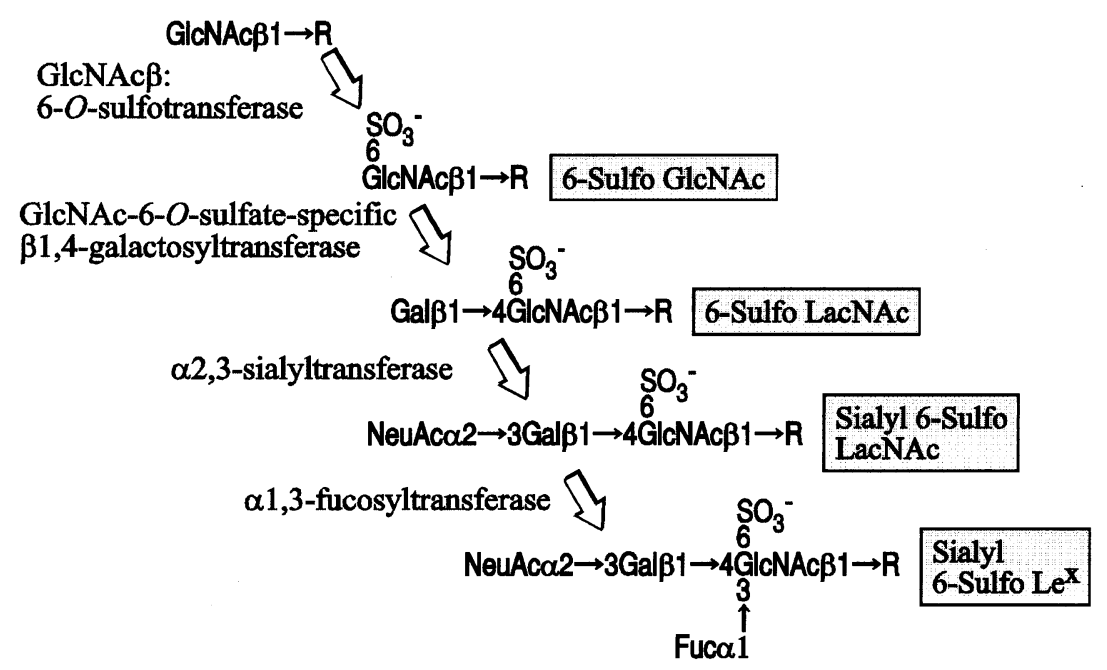

Fig. 3. Proposed synthetic pathway for sialyl 6-sulfo Lewis x.

lite members shown in Fig. 4; genuine sialyl 6-sulfo Lewis $\mathrm{x}$, de- $N$-acetyl sialyl 6-sulfo Lewis $\mathrm{x}$, and cyclic sialyl 6-sulfo Lewis $\mathrm{x}(46)$.

The first evidence for the presence of cyclic sialyl 6-sulfo Lewis $\mathrm{x}$ was obtained by a monoclonal antibody approach (46). The MoAb G159 ( $\left.\operatorname{IgG}_{1}\right)$, which was obtained from the same fusion as G152, was initially shown to be incidentally directed to one of the minor and heterogenous by-products of organochemical synthesis, contaminated in the synthetic sialyl 6-sulfo Lewis $x$ preparation (46). The by-products had been accidentally produced by the excessive deacetylation under anhydrous conditions at the final step during the organ-chemical synthesis of sialyl 6-sulfo Lewis $\mathrm{x}$, and therefore they were predicted to be produced by deacetylation and/or dehydration of the target compound. The by-product defined by the G159 antibody was sialidase-resistant, suggesting that sialic acid moiety is modified in this by-product. The by-product had a much higher TLC mobility than the target compound, compatible with the formation of an intramolecular ring, such as lactone or lactam structure, by dehydration. The remarkable stability of the G159-defined by-product against alkaline treatment supported the presence of a lactam structure, rather than a lactone ring in the sialic acid moiety. However, further characterization of the synthetic contaminants was not possible, since they were highly heterogenous. The synthetic sialyl 6-sulfo Lewis $\mathrm{x}$ glycolipid contained three minor contaminants which migrated faster than the authentic substance, and the G159 antibody was reactive to the second fast-migrating component. The amount of the G159defined contaminant was very small and highly lot-dependent.

For the elucidation of the antigenic structure recognized by the G159 antibody, we designed an intentional de novo synthesis of de- $N$-acetyl sialyl 6-sulfo Lewis x, the first candidate for the excessively deacetylated products (47), and dehydrated
デ-N-アセチルシアル酸に変え、さらにサイクリックシアル酸に 変化させる経路である。

この問題は、抗シアリル6-スルホルイスx抗体を樹立する過 程で副産物として得られた抗体G159によって解決の糸口が見つ かった(46)。G159抗体 $\left(\mathrm{IgG}_{1}\right)$ は、先に述べたG152抗体と同じ フュージョンから得られた抗体で、単クローン抗体作成の際に 抗原として用いた有機合成シアリル6-スルホルイスxにたまたま 含まれていた、極めて微少な合成副産物に対して生じた抗体で ある(46)。この合成副産物は、合成の最終段階で、無水条件下で の脱アセチル反応が過度であったために生じたと考えられたの で、本来の化合物が、脱アセチル化と脱水を受けたものと推定 された。G159抗体と反応する合成副産物はシアリダーゼ耐性な ので、この変化はシアル酸部分に起こっていると考えられた。 その反応バンドは、本来のシアリル6-スルホルイスxよりも大き なTLC易動度を持つので、脱水反応によりラクトン環あるいは ラクタム環が形成されていると考えられたが、アルカリに耐性 であることから、ラクタム環の可能性が高いと推定された。し かし、それ以上の解析は、合成副産物の組成が複雑であるため に不可能であった。この合成品は、本来の化合物よりも大きな TLC易動度を持つ合成副産物を少なくとも三種含んでおり、 G159抗体が認識するのは、そのうちの二番目のTLC易動度をも つ物質だったのである。この抗原はたいへん少量であり、しか も、ロットによって含量が異なっていた。

有機合成した抗原中の合成副産物は、無水条件下での過度 の脱アセチル化によって生じたと推定されたので、シアル酸の $N$-アセチル基を欠くデ- $N$-アセチルシアリル6-スルホルイス あらためて有機合成し(47)、これをWSC（water-soluble 

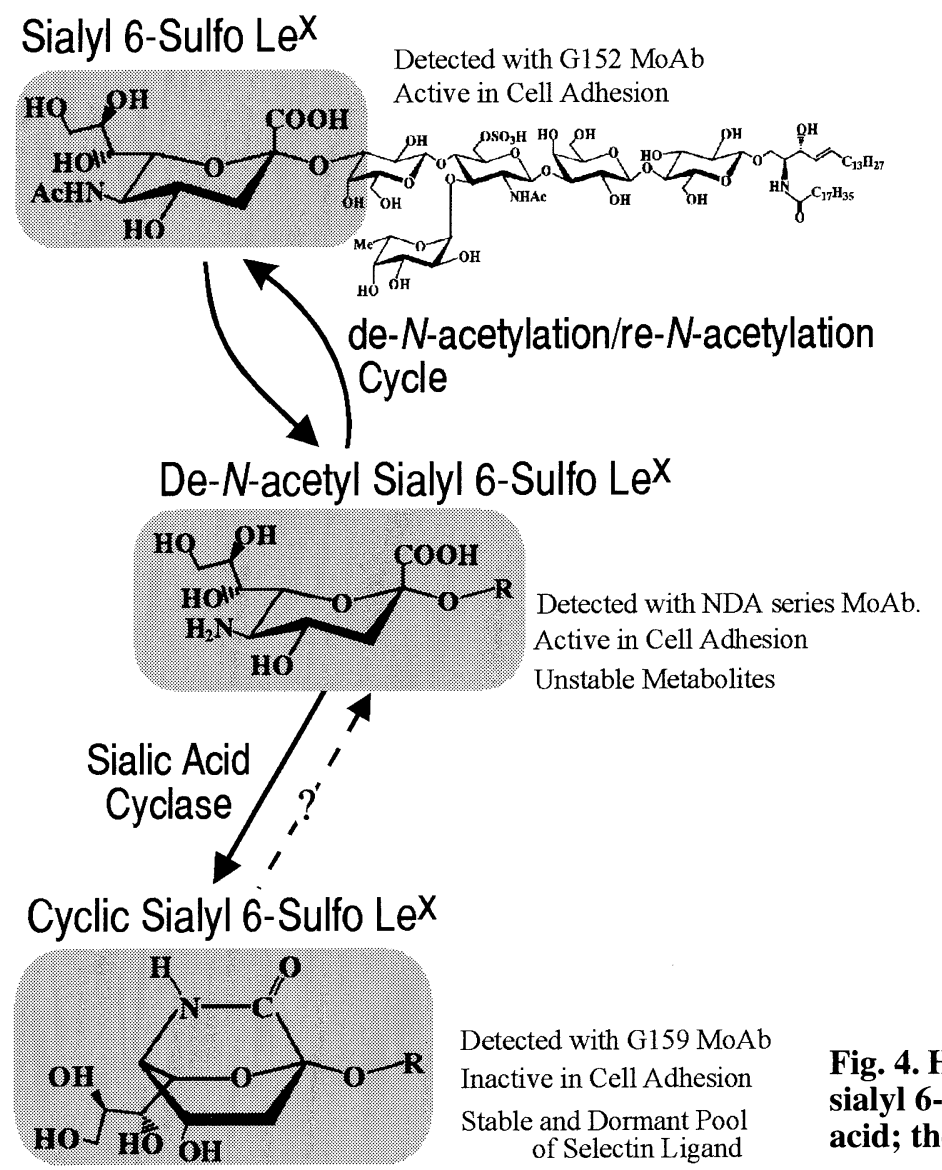

Detected with G159 MoAb Inactive in Cell Adhesion Stable and Dormant Pool of Selectin Ligand
Fig. 4. Hypothetical metabolic pathway of sialyl 6-sulfo Lewis $x$ by cyclization of sialic acid; the cyclic sialic acid pathway. the synthetic product with a water-soluble carbodiimide reagent. This quantitatively yielded a G159-reactive substance having the same TLC mobility as the initial by-product defined by the G159 antibody. By mass-spectrometric analysis, it was confirmed that the antigenic determinant recognized by the G159 antibody was the dehydration product of de- $N$-acetyl sialyl 6sulfo Lewis $\mathrm{x}$ (48). The remarkable resistance of the de novo synthesized genuine G159-defined substance to alkaline treatment confirmed again that a lactam ring was formed within the sialic acid moiety by the dehydrative condensation with the carbodiimide reagent (46).

\section{Physiological Significance of Cyclic Sialyl 6-Sulfo Lewis x and Cyclic Sialic Acid Pathway}

The cyclic sialyl 6-sulfo Lewis $\mathrm{x}$ determinant defined by the G159 antibody is produced in vitro from de- $N$-acetyl sialyl 6-sulfo Lewis $x$ by an enzyme called sialic acid cyclase, which is a calcium-dependent neutral enzyme (46). Activation of cultured lymphoid cells with TPA strongly induces expression of cyclic sialyl 6-sulfo Lewis $\mathrm{x}$ and a proportional decrease of genuine sialyl 6-sulfo Lewis $\mathrm{x}$ expression, which is accompanied with an increment of sialic acid cyclase activity (46). This suggested that the conversion of genuine sialyl 6-sulfo Lewis $x$ to cyclic sialyl 6-sulfo Lewis $x$ through the pathway illustrated in Fig. 4 carbodiimide）で脱水処理した。すると、先の合成不純物とおな じTLC易動度を持ち、G159抗体と良く反応する産物が得られ た。FAB-MAS解析によって、G159の認識抗原は、デ-N-アセチ ルシアリル6-スルホルイスxが脱水されたものであることが確認 され(48)、環の構造は、産物がアルカリ耐性であることからラク 夕ム環である可能性が一層高くなった(46)。

I. サイクリックシアリル6-スルホルイスxとサイクリックシアル 酸経路の生理的意義

G159抗体の認識抗原サイクリックシアリル6-スルホルイス $\mathrm{x}$ は、中性領域に至適 $\mathrm{p} \mathrm{H}$ を持つカルシウム依存性酵素、シアル 酸シクラーゼのはたらきによって、デ-N-アセチルシアリル6-ス ルホルイスxから in vitroで形成される(46)。リンパ球系細胞を TPAで活性化すると、サイクリックシアリル6-スルホルイス $\mathrm{x}$ の 発現が誘導され、これに比例してシアリル6-スルホルイス $\mathrm{x}$ の発 現が逆に減少して行くのが観察される。このときシアル酸シク ラーゼの活性も上昇する(46)。この実験結果は、リンパ球系細胞 のTPA刺激によって図4の経路がはたらき、シアリル6-スルホル イスxがサイクリックシアリル6-スルホルイスxに変えられたこ とを強く示唆する。サイクリックシアリル6-スルホルイスxは、 
occurs in TPA-stimulated lymphocytes. The cyclic sialyl 6-sulfo Lewis $\mathrm{x}$ determinant has virtually no binding activity to selectins because the modification occurred at the carboxyl residue of the sialic acid moiety essential for the interaction with selectins, while genuine and de- $N$-acetyl sialyl 6-sulfo Lewis x retain their binding activity to selectins. This indicates that the sialic acid cyclase pathway has physiological significance as a negative feedback system for the selectin ligand activity on leukocytes.

On the other hand, expression of conventional sialyl Lewis $\mathrm{x}$ is known to increase through the TPA stimulation of lymphocytes, that is known to accompany induction of Fuc-T VII mRNA $(49,50)$. When human peripheral lymphocytes are stimulated by TPA, expression of sialyl 6-sulfo Lewis $\mathrm{x}$ is diminished, and a remarkable induction of conventional sialyl Lewis x is observed (Ohmori, K., Mitsuoka, C., Kanamori, A., Kurata-Miura, K., Sasaki, K., Nishi, T., Uchimura, K., Muramatsu, T., and Kannagi, R., manuscript in preparation). This is a good example indicating that the expression of sialyl 6-sulfo Lewis $\mathrm{x}$ is regulated differently from conventional sialyl Lewis $\mathrm{X}$.

Both genuine and cyclic sialyl 6-sulfo Lewis $\mathrm{x}$ determinants defined by the G152 and G159 antibodies are preferentially expressed on a part of helper memory $\mathrm{T}$ cells and NK cells. The characteristics of helper memory $\mathrm{T}$ cells which express these determinants coincided with those of previously-reported skin homing T lymphocytes [(46), and Ohmori, K., et al., manuscript in preparation]. This suggests that the sialic acid cyclase pathway would be functional in these cell populations. It is noteworthy that the resting helper memory $\mathrm{T}$ cells, which undergo skin homing in normal individuals, significantly expressed the determinant, without any sign of inflammatory diseases. This finding suggests that the determinant may serve as a ligand for selectins in routine trafficking of leukocytes in healthy individuals. The presence of a distinct metabolic pathway to inactivate the adhesive activity of the determinant through the conversion to cyclic sialyl 6-sulfo Lewis $\mathrm{x}$ implies that this routine trafficking is under a strict control system which effectively prevents excessive accumulation of leukocytes. The disappearance of the determinant upon stimulation of the cells suggests that the determinant may not have a positive role in inflammation, whereas conventional sialyl Lewis $\mathrm{x}$ would play a major role as its expression is strongly induced upon inflammatory stimulation. It is noteworthy that the sialyl 6-sulfo Lewis $\mathrm{x}$ determinant expressed on the HEV endothelial cells mediates homing of lymphocytes to lymph nodes, which is also an example of routine trafficking of lymphocytes, occurring in healthy individuals without any sign of inflammatory diseases. One may thus assume that sialyl 6-sulfo Lewis $\mathrm{x}$ is mainly engaged in the routine trafficking of leukocytes, and conventional sialyl Lewis $\mathrm{x}$ is involved in the extensive and irreversible mobilization of leukocytes in inflammation.
セレクチンとの結合に最も大切とされるカルボキシル基が修飾 を受けたため、リガンド活性をもたない。これに対し、デ-N-ア セチルシアリル6-スルホルイスxやもとのシアリル6-スルホルイ スxには、細胞接着活性が保持されている。このことから、シア ル酸シクラーゼ経路は、白血球のセレクチンへの結合活性を不 活化するネガティブ・フィードバック機構としての意義を持つ と思われる。

一方、通常のシアリルルイス $\mathrm{x}$ の発現は、TPA刺激によって むしろ強く誘導されることが知られている。この時、Fuc-TVII のmRNAの誘導が起こることも良く知られている $(49 、 50) 。 こ の ~$ ため、ヒト末梢血リンパ球をTPAで刺激すると、シアリル6-ス ルホルイス $\mathrm{x}$ の発現が消失し、かわりに通常のシアリルルイス $\mathrm{x}$ の発現が強く誘導される(Ohmori, K., Mitsuoka, C., Kanamori, A., Kurata-Miura, K., Sasaki, K., Nishi, T., Uchimura, K., Muramatsu, T., and Kannagi, R., 投稿準備中)。このように、シアリル6-スルホル イス $\mathrm{x}$ 通常のシアリルルイス $\mathrm{x}$ の発現は、その調節機構に大き な差異がある。

シアリル6-スルホルイスxもサイクリックシアリル6-スルホ ルイス $\mathrm{x}$ 、リンパ球ではヘルパーメモリーT細胞と $\mathrm{NK}$ 細胞に発 現している。これらを発現するへルパーメモリーT細胞の特徴 を解析すると、以前に皮膚へホーミングするT細胞とされてい たサブセットの特徵と一致する(46、および Ohmori, K., ほか, 投 稿準備中)。すなわち、シアル酸シクラーゼ経路は、皮膚へホー ミングするT細胞ではたらいているように思われる。シアリル6スルホルイスxが、炎症などの病変とは無関係に、健常人におい て皮虐へホーミングするヘルパーメモリーT細胞に発現してい る点は注目される。シアリル6-スルホルイスxは、炎症ではなく むしろ健常人における日常的なリンパ球の移動に関与している 可能性が高いと考えられる。この糖鎖が、独特な代謝経路で不 活化されることも、日常的な皮膚へのホーミングにおいて白血 球の過度な集積を避けるためであろうと考えられる。シアリル 6-スルホルイスxは、炎症性刺激によって消失するので、炎症時 の白血球の動員にはあまりかかわっていないであろう。一方、 通常のシアリルルイスxは、炎症時に強く発現が誘導され、炎症 時の白血球動員の主役を演じると考えられる。リンパ節のHEV に発現するシアリル6-スルホルイスxが媒介するのもまた、リン パ球のリンパ節へのホーミングであり、これも炎症などの病的 状態とは関わりなく、日常的に行われる移動である。このよう に、シアリル6-スルホルイスxは、主として健常人の体内で日常 的におこるリンパ球の正常な移動においてはたらくリガンドで あると考えられる。これに対して、通常のシアリルルイスxは、 炎症時の不可逆的でしかも大規模な白血球の非常時動員におい て働くリガンドであると考えられる。 
Trends in Glycoscience and Glycotechnology Vol.11 No.62 ((November 1999) pp.329-344

\section{References}

1. Lowe, J.B., Stoolman, L.M., Nair, R.P., Larsen, R.D., Berhend, T.L., and Marks, R. M. (1990) Cell 63, 475-484

2. Phillips, M.L., Nudelman, E., Gaeta, F.C.A., Perez, M., Singhal, A. K., Hakomori, S., and Paulson, J.C. (1990) Science 250, 1130-1132

3. Walz, G., Aruffo, A., Kolanus, W., Bevilacqua, M., and Seed, B. (1990) Science 250, 1132-1135

4. Takada, A., Ohmori, K., Takahashi, N., Tsuyuoka, K., Yago, K., Zenita, K., Hasegawa, A., and Kannagi, R. (1991) Biochem. Biophys. Res. Commun. 179, 713-719

5. Tyrrell, D., James, P., Rao, N., Foxall, C., Abbas, S., Dasgupta, F., Nashed, M., Hasegawa, A., Kiso, M., Asa, D., Kidd, J., and Brandley, B.K. (1991) Proc. Natl. Acad. Sci. USA 88, 10372-10376

6. Takada, A., Ohmori, K., Yoneda, T., Tsuyuoka, K., Hasegawa, A., Kiso, M., and Kannagi, R. (1993) Cancer Res. 53, 354-361

7. Sawada, M., Takada, A., Ohwaki, I., Takahashi, N., Tateno, H., Sakamoto, J., and Kannagi, R. (1993) Biochem. Biophys. Res. Commun. 193, 337-347

8. Mitsuoka, C., Kawakami-Kimura, N., Kasugai-Sawada, M., Hiraiwa, N., Toda, K., Ishida, H., Kiso, M., Hasegawa, A., and Kannagi, R. (1997) Biochem. Biophys. Res. Commun. 230, 546-551

9. Mitsuoka, C., Sawada-Kasugai, M., Ando-Furui, K., Izawa, M., Nakanishi, H., Nakamura, S., Ishida, H., Kiso, M., and Kannagi, R. (1998) J. Biol. Chem. 273, 11225-11233

10. Kimura, N., Mitsuoka, C., Kanamori, A., Hiraiwa, N., Uchimura, K., Muramatsu, T., Tamatani, T., Kansas, G.S., and Kannagi, R. (1999) Proc. Natl. Acad. Sci. USA 96, 4530-4535

11. Gallatin, W.M., Weissman, I.L., and Butcher, E.C. (1983) Nature 304, 30-34

12. Geoffroy, J.S. and Rosen, S.D. (1989) J. Cell Biol. 109, 2463-2469

13. Walcheck, B., Kahn, J., Fisher, J.M., Wang, B.B., Fisk, R.S., Payan, D.G., Feehan, C., Betageri, R., Darlak, K., Spatola, A.F., and Kishimoto, T.K. (1996) Nature 380, 720-723

14. Walcheck, B., Moore, K.L., McEver, R.P., and Kishimoto, T. K. (1996) J. Clin. Invest. 98, 1081-1087

15. Akahori, T., Yuzawa, Y., Nishikawa, K., Tamatani, T., Kannagi, R., Miyasaka, M., Okada, H., Hotta, N., and Matsuo, S. (1997) J. Immunol. 158, 5384-5392

16. Seko, Y., Enokawa, Y., Tamatani, T., Kannagi, R., Yagita, H., Okumura, K., and Yazaki, Y. (1996) J. Pathol. 180, 305-310

17. Kannagi, R. (1998) in Leukocyte Typing VI (Kishimoto, T., Kikutani, H., von dem Borne, E.G. Kr., Goyert, S.M., Mason, D.Y., Miyasaka, M., Moretta, L., Okumura, K., Shaw, S., Springer, T.A., Sugamura, K., and Zola, H., eds) pp. 352-355, Garland Publishing Inc., New York

18. Streeter, P.R., Rouse, B.T., and Butcher, E.C. (1988) J. Cell Biol. 107, 1853-1862

19. Imai, Y., Lasky, L.A., and Rosen, S.D. (1993) Nature 361, 555-557

20. Hemmerich, S., Butcher, E.C., and Rosen, S.D. (1994) J. Exp. Med. 180, 2219-2226

21. Hemmerich, S., Leffler, H., and Rosen, S.D. (1995) J. Biol. Chem. 270, 12035-12047

22. Hemmerich, S., and Rosen, S.D. (1994) Biochemistry 33, 4830-4835

23. Maly, P., Thall, A. D., Petryniak, B., Rogers, G.E., Smith, P.L., Marks, R.M., Kelly, R.J., Gersten, K.M., Cheng, G.Y., Saunders, T.L., Camper, S. A., Camphausen, R. T., Sullivan, F. X., Isogai, Y., Hindsgaul, O., Von Andrian, U.H., and Lowe, J.B. (1996) Cell 86, 643-653

24. Habuchi, O., Suzuki, Y., and Fukuta, M. (1997) Glycobiology 7, 405-412

25. Tsuboi, S., Isogai, Y., Hada, N., King, J.K., Hindsgaul, O., and Fukuda, M. (1996) J. Biol. Chem. 271, 27213-27216

26. Galustian, C., Lawson, A.M., Komba, S., Ishida, H., Kiso, M., and Feizi, T. (1997) Biochem. Biophys. Res. Commun. 240, 748-751

27. Yoshino, K., Ohmoto, H., Kondo, N., Tsujishita, H., Hiramatsu, Y., Inoue, Y., Kondo, H., Ishida, H., Kiso, M., and Hasegawa, A. (1997) J. Med. Chem. 40, 455-462

28. Uchimura, K., Muramatsu, H., Kadomatsu, K., Fan, Q.W., Kurosawa, N., Mitsuoka, C., Kannagi, R., Habuchi, O., and Muramatsu, T. (1998) J. Biol. Chem. 273, 22577-22583

29. Takahashi, K., Sawasaki, Y., Hata, J., Mukai, K., and Goto, T. (1990) In Vitro Cell Dev. Biol. 26, 265-274

30. Lasky, L.A., Singer, M.S., Dowbenko, D., Imai, Y., Henzel, W. J., Grimley, C., Fennie, C., Gillett, N., Watson, S.R., and Rosen, S.D. (1992) Cell 69, 927-938

31. Baumhueter, S., Singer, M.S., Henzel, W., Hemmerich, S., Renz, M., Rosen, S.D., and Lasky, L.A. (1993) Science 262, 436-438

32. Derry, C.J., Faveeuw, C., Mordsley, K.R., and Ager, A. (1999) Eur. J. Immunol. 29, 419-430

33. Sassetti, C., Tangemann, K., Singer, M.S., Kershaw, D.B., and Rosen, S.D. (1998) J. Exp. Med. 187, 1965-1975

34. Tu, L., Delahunty, M.D., Ding, H., Luscinskas, F.W., and Tedder, T.F. (1999) J. Exp. Med. 189, 241-252

35. Spertini, O., Cordey, A.S., Monai, N., Giuffrè, L., and Schapira, M. (1996) J. Cell Biol. 135, 523-531

36. Guyer, D.A., Moore, K.L., Lynam, E.B., Schammel, C.M.G., Rogelj, S., McEver, R.P., and Sklar, L.A. (1996) Blood 88, 2415-2421

37. Tu, L.L., Chen, A.J., Delahunty, M.D., Moore, K.L., Watson, S.R., McEver, R.P., and Tedder, T.F. (1996) J. Immunol. 157, 3995-4004

38. Uchimura, K., Muramatsu, H., Kaname, T., Ogawa, H., Yamakawa, T., Fan, Q.W., Mitsuoka, C., Kannagi, R., Habuchi, O., Yokoyama, I., Yamamura, K., Ozaki, T., Nakagawara, A., Kadomatsu, K., and Muramatsu, T. (1998) J. Biochem. (Tokyo) 124, 670-678

39. Fan, Q.W., Uchimura, K., Yuzawa, Y., Matsuo, S., Mitsuoka, C., Kannagi, R., Muramatsu, H., Kadomatsu, K., and Muramatsu, T. (1999) Glycobiology 9, 947-955

40. Bistrup, A., Bhakta, S., Lee, J.K., Belov, Y.Y., Gunn, M. D., Zuo, F.-R., Huang, C.-C., Kannagi, R., Rosen, S.D., and Hemmerich, S. (1999) J. Cell Biol. 145, 899-910

41. Hiraoka, N., Petryniak, B., Nakayama, J., Tsuboi, S., Suzuki, M., Yeh, J-C., Izawa, D., Tanaka, T., Miyasaka, M., Lowe, J.B., and Fukuda, M. (1999) Immunity 11, 79-89

42. Lee, J.K., Bhakta, S., Rosen, S.D., and Hemmerich, S. (1999) Biochem. Biophys. Res. Commun. 263, 543-549

43. Spiro, R. G., Yasumoto, Y., and Bhoyroo, V. (1996) Biochem. J. 319, 209-216

44. Degroote, S., Lo-Guidice, J. M., Strecker, G., Ducourouble, M. P., Roussel, P., and Lamblin, G. (1997) J. Biol. Chem. 272, 29493-29501

45. Seko, A., Hara-Kuge, S., Yonezawa, S., Nagata, K., and Yamashita, K. (1998) FEBS Lett. 440, 307-310

46. Mitsuoka, C., Ohmori, K., Kimura, N., Kanamori, A., Komba, S., Ishida, H., Kiso, M., and Kannagi, R. (1999) Proc. Natl. Acad. Sci. USA 96, $1597-1602$ 
47. Komba, S., Galustian, C., Ishida, H., Feizi, T., Kannagi, R., and Kiso, M. (1999) Angew. Chem. (Engl) 38, 1131-1133

48. Kannagi, R., Mitsuoka, C., Ohmori, K., Kanamori, A., Khoo, K. -H., and Inoue, Y. (1999) in Sialobiology and Other Novel Forms of Glycosylation (Inoue, Y., Lee, Y.C., and Troy, F.A., eds) pp. 37-43, Gakushin Publishing Co., Osaka, Japan

49. Knibbs, R.N., Craig, R.A., Natsuka, S., Chang, A., Cameron, M., Lowe, J.B., and Stoolman, L. M. (1996) J. Cell Biol. 133, 911-920

50. Hiraiwa, N., Hiraiwa, M., and Kannagi, R. (1997) Biochem. Biophys. Res. Commun. 231, 183-186

Received on October 25, 1999, accepted on December 3, 1999

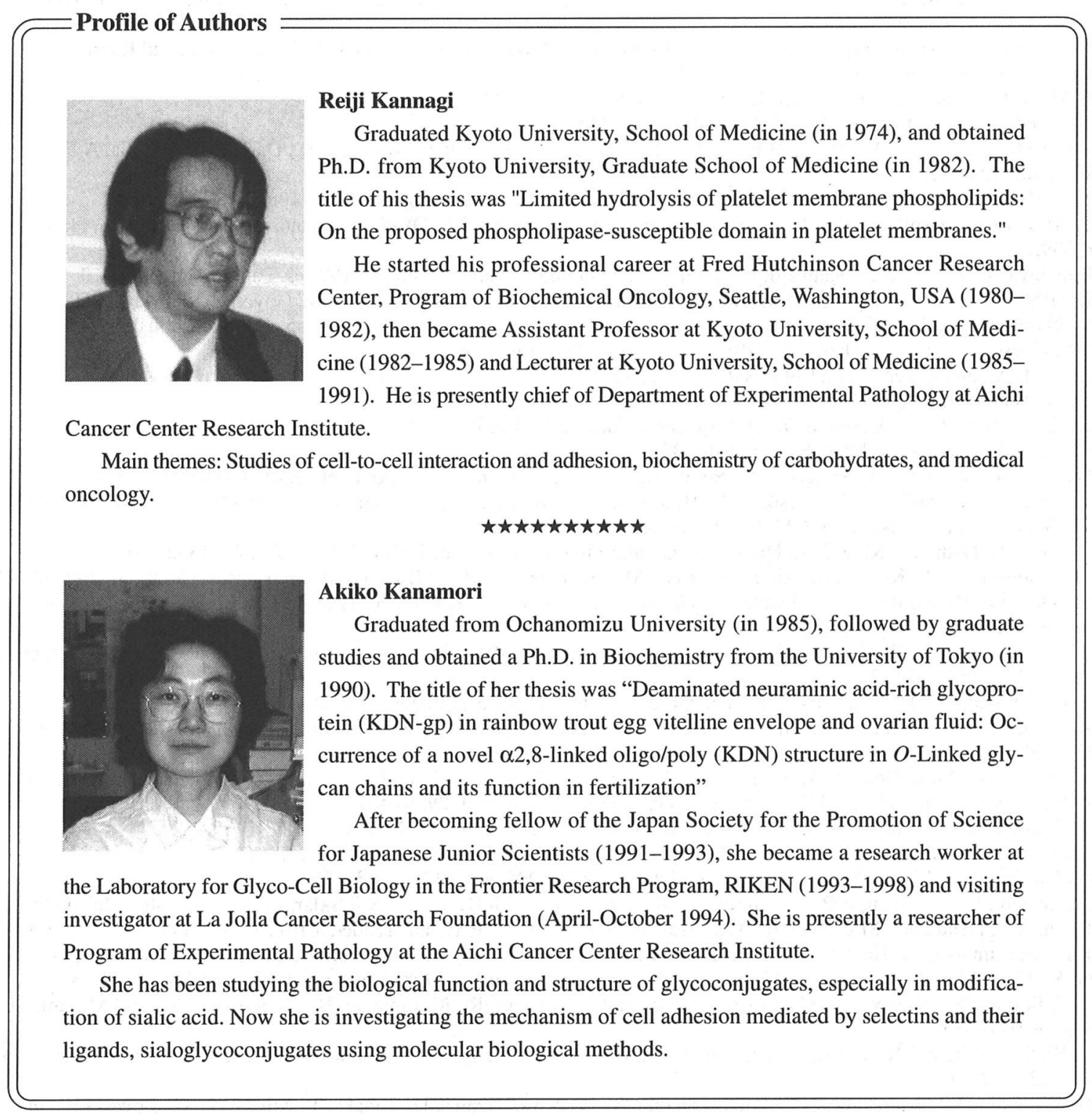

